Lashari Kurdashvili

Tbilisi State University, Tbilisi, Georgia

Iasha Meskhia

Tbilisi State University, Tbilisi, Georgia

Ministry of the Regional Development and Infrastructure of Georgia

UDC 005.963:338.48

338.486 .3

\title{
THE ROLE OF HUMAN CAPITAL IN THE DEVELOPMENT OF TOURISM BUSINESS
}

\begin{abstract}
The paper discusses that the main condition for the development of enterprises of hospitality industry is human capital. It shows that the continuous education of employees in this area is an important factor in the reproduction of human capital.

The author believes that tourism is one of the most dynamic sectors of Georgian economy in recent decades. The objectives of this foundation are: the unique natural resources, convenient geographical location and other factors, which contribute to the attractiveness of Georgia.

The paper examines the socio-economic services and tourism development prospects of the Black Sea Coast, noted that intensification of problems in this field is primarily concerned with the following: the existence of human capital, its quality and its reproduction.
\end{abstract}

\section{Introduction}

One of the main factors in progress of any tourism industry component is the development of human capital. Employees continue education providing rapid growth of the Georgian tourism industry in region and increasing of sector's competitiveness.

In recent years, tourism has become one of the most dynamically developing priority direction of Georgian economy. Tourism and hospitality industry attractiveness is due to the country's unique diversity of natural resources, cultural and historical monuments, sea and mountain resorts, curative mineral and thermal waters, favorable geographic
According to the author, problems increasingly arise in all regions of Georgia. In comparison with other countries in which the service has become the most profitable sector, Georgian hospitality industry is only now developing and the socio-economic development of the country is connected with the role of the human factor.

In our opinion, in time solutions of problems in the sector will contribute to the socio-cultural development and perfection. Such an approach will make it possible to satisfy the demand for an active and full relaxation in the country.

Key words: human capital, diversified education system, quality of service, social and cultural development.

location and many other positive factors. However, today's post-Soviet Georgia tourism industry is still weak and is in formation-development process. State government realized significant and positive measures to support tourism sector, improved legal framework, introduced preferential taxes, tourism businesses became available for sale of state and bank loans, foreign investment was attracted to the winter ski resorts, hotels, holiday homes, roads and other tourism infrastructure facilities construction.

Tourism business-friendly legal and economic environment, infrastructure rehabilitation and development, security system and other positive socio-economic 
changes important catalyst for the development of this sector. In 2005-2013 in Georgia visitors (tourists) amounts grew by $33 \%$ on average. In 2014, the growth rate has been reduced compared to previous year, which was caused by the economic difficulties in the region, as well as toughening of visa regulations on migration made in Georgian legislation (Meskhia I., Asatiani R., 2012). However, after enactment negatively affected on the tourist number visiting the country, these regulations have been mitigated. In 2015, visitors number totaled the record 5.89 million people (Figure 1), while in 2000 it figured 388 thousand, and in 2010 it did not exceed 2.1 million (Georgian National Tourism Administration).
In the same year income from foreign tourism amounted to 1.8 billion dollars that was country's gross domestic product $6 \%$. In sectors associated with tourism (transport, restaurants, hotels, etc.), jobs number is about 200 thousand units, which equals to $11 \%$ of the whole employees number in country. Direct jobs number reaches 85000 that were $4.8 \%$ of employees (Figure 1 ). The last data contained employment in hotels, travel agencies, passenger transportation services, restaurants and leisure industry, which is directly supported by tourists (World Travel and Torusim Council, 2015).

Figure 1. International Arrivals in Georgia per Year

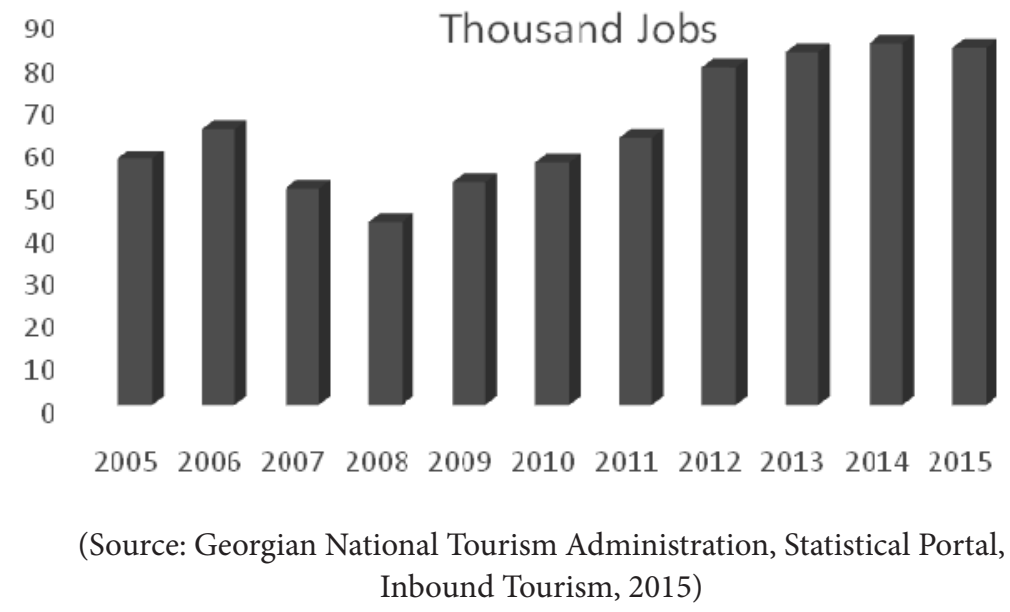

In ranking of Travel and Tourism Competitiveness Index (T \& TCI) for 201, Georgia took $71^{\text {st }}$. In the same ranking Georgia took $73^{\text {rd }}$ place in 2011, which indicates that the situation in country in terms of tourism has positive change. In 2015, Georgia's ranking improved by following indicators: tour- ism infrastructure, air transport infrastructure, health and hygiene, environmental sustainability, safety and security, and worsened for indicators such as price competitiveness, prioritization of travel and tourism, road and port infrastructure (Travel and Tourism Competitiveness Report, 2015). 
Figure 2. Direct Contribution of Travel \& Tourism to Employment

\section{International arrivals by years}

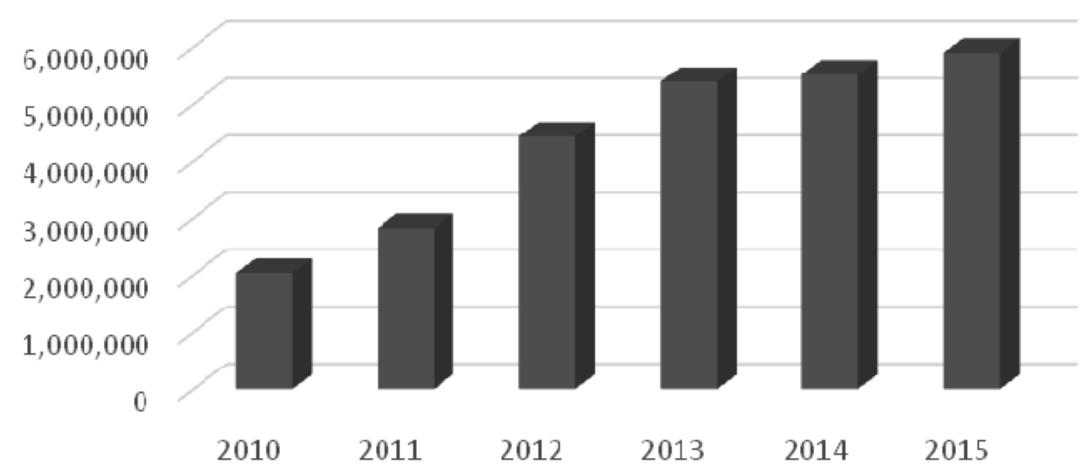

(Source: World Travel and Tourism Council, The Economic Impact of Travel \& Tourism, Georgia, 2015)

Georgia Tourism almost $90 \%$ comes from neighboring countries (Turkey $-26 \%$, Azerbaijan - 23\%, Russia - 15\%, Armenia - 24\%, Ukraine - 3\%), while 10 percent - from other countries, leading by Poland, Israel, Germany, Kazakhstan and so on. Georgia is represented by almost all tourism types, including cultural tourism $-41 \%$, housing $-18 \%$, ecotourism $-6 \%$, the sports tourism $-3 \%$, agro tourism $-2 \%$, wine tourism $-2 \%$, adventure tourism $-2 \%$, other tourism types - 26\% (Georgian National Tourism Administration). Especially forecasted wine tourism expected growth would be marked, as Georgia is considered as historically unique and high-quality wine-producing country, and accordingly there exists very high interest in foreign tourists towards country. Also traditional hospitality of rural area residents should be considered, which can positively influence foreign tourists towards local population.

Tourism development has very specific meaning for Georgia. The fact is that country's foreign trade $80 \%$ comes on import and, due to underdevelopment of real sec- tor and goods low competitiveness, the export volume does not exceed 20\%. (National Statistics Office of Georgia). Consequently country suffers from the foreign currency shortage, which leads to destabilization of macroeconomic equilibrium, exchange rate falling and provokes inflationary pressures. Therefore, international tourism is regarded as one of the major sources of foreign currency inflows in country, and therefore, as an regulation instrument for macroeconomic stability and exchange rate policy.

In Georgia among positive institutional and macro-economic circumstances supporting tourism development, the following should be noted: the development of the banking sector and the high level of dynamism; currency liberalization; well-developed rail, maritime, air transport and their infrastructure; national telecommunications system integration in international system; successful implementation of anti-corruption measures; eco-liberal economic reforms; mitigation of tax burden; streamline customs and tariffs; EU Association Agreement; visa-free regime with EU countries; 
free trade agreements with foreign countries; free economic zones; investment climate improvement; protection of consumers, etc. (Meskhia I., 2010).

The Government of Georgia offers a range of benefits to persons interested in hotel business investment in tourist zones: the investor shall be exempted from the Tax Code of the property tax and income tax obligation for 15 years, as well as building permits and fee payment obligations. The land shall be transferred to the investor at the symbolic price - 1 GEL. In addition by the cooperation with the Partnership Fund the investment in tourist sector is possible. The fund offers co-funding and participation to private investors. With PF's co-participation have been already implemented several successful projects such as: Hotel "Royal Batoni” in Kvareli, hotel "Gino Wellness"; Spa "Rixos Borjomi” and mineral water resort in Likani, resort complex in Sairme.

Among the weaknesses of tourism development in Georgia it should be noted: human capital development low level and tourism service low quality, as well as the high price of travel services, in comparison with neighboring Turkey and many other tourist countries.

In modern era of globalization the competitive battle in tourism sector especially has intensified, the number of countries attracting foreign tourists by ambitious plans has been increased. Tourism has become one of the most attractive areas for business not only for profit, but also its social role and purpose have been increased. Tourism has become for peoples, countries and regions cultural relations and spiritual convergence tool. That is why today in delivery of tourist product human capital takes special place, which is the material, financial and infrastructural capital, together with tourism development is the important component of modern creativity.

In scientific literature is often generalized (simplified) definition of the notion of "human capital". For example, the most common definition: "human capital is the complexity of human knowledge, practical skills and labor efforts, or combination of human talent and available data, which we have to admit as the special capital form" (Stewart T.A., 2005). We believe that human capital is the unity of knowledge, skills and practical experiences that provide different types of profit and competitive advantage in the battle; this is the result of accumulated investments in particular embodiment of human health, knowledge, skills, talent and motivation of a certain stock, which is used in the production of any given field. All of the above stated, contribute to the specific human labor productivity, wages and production efficiency.

One of the main problems in Georgian hospitality industry is the lack of qualified personnel. Creating of favorable environment for tourism development can only be the continuous education and practical skills through the creation of coherent system. People status in labor market and employment is depending on the education level and quality. The employer chooses well paid staff and good service, takes orientation on education level and the selection criteria takes her everywhere, without exception.

The tourism business practice is focused on their own business interests. They need specialists, who possess specific skills, able to quick profession adaptation, have service mentality. Such training needs good theoretical and scientific base, including systematic analysis of methodology and process approaches. But in no case well-skilled people (for example, a foreign language or multiple computer program experts) cannot be equalized with vocational training specialists. The education process is very long and difficult, therefore, is not appropriate its separation from moral, social and aesthetic education process.

Tourism education has become one of the most demanded destinations in higher 
education and vocational education network. This is evidenced not only in large number of enrolled students in tourism profile, but also their high level of academic mobility in favor of tourism. This is due to primarily two criteria. First, tourism as the country's economy is important for the state to preserve the financial, material and political support. Second, tourism as priority sector by developing rate created largest number of new jobs in the country and, therefore, assumes the stimulation function of youth employment. Therefore, in almost all of the country's leading universities and colleges there are operating undergraduate, graduate and doctoral programs of tourism direction.

In Georgian Universities tourism business training programs are focused on obtaining of basic university education, on teaching of tourism business management theory and practice, on introduction of modern technological advances in tourism industry, on the practical skills in tourism business. Universities and colleges are oriented on training of highly qualified and competitive specialists in tourism sector. In highly-rated universities there are developed and implemented undergraduate, graduate and doctoral programs corresponding to the international standards.

Together with local professors learning processes involve also foreign lecturers and specialists. Exchange programs have been operating for students and professors. Foreign tourist textbooks and other educational literature have been translated into Georgian language. Joint training and research programs with foreign universities and tourist centers have been functioning. Simulation centers have been established at universities, where students work similar to real companies on the establishment and operation of the company. In addition students have internships in the real tourist companies, carried out the development of tourism products, and are involved in the company's management and personnel policy, as well as marketing and sales strategy.

Tourism bachelors, masters and $\mathrm{PhD}$ programs are in progress in various authorized universities, among which following should be highlighted: Ivane Javakhishvili Tbilisi State University, Ilia State University, Georgia Technical University, Shota Rustaveli State University, Kutaisi State University and others. In addition, preparation of specialists in tourism field takes place in different educational universities and colleges. Georgian educational centers in tourism field carry out joint programs, student and faculty exchanges, research and other enabling activities with foreign educational centers, such as South Carolina State University (USA), University of Mugla (Turkey), Vilnius University, Poland Adam Mickiewicz Institute, Schwerin and Eberswalde Universities (Germany), University of Telemark (Norway), Hamburg European business school, etc.

Preparation of the professional staff (the restaurant manager, bartender, hotel manager, the reception, tour operators, etc.) in tourist infrastructres takes place in numerous colleges, mainly in tourist zones: in Kobuleti - Tourism College "New Wave", in Batumi - college - "Bleski", in Tbilisi - Tourism Training Center- "Geo-training" and other. Serving staff are prepared for hotels (Marriott, Radisson, Sheraton and other international brands), modern hotels, restaurants and bars.

International Tourism School representatives are active in Georgia, including world's leading educational network in the field of the hospitality, "Loretta Group". Its Les Roche and Glion schools have begun training in Georgia and plan to hold tourism training center, where invited foreign consultants will prepare highly trained staff in tourism industry.

The recent positive changes implemented in Georgian tourism business indicate on the raised qualification and skill level of human capital. For example, activities have been 
enhanced towards popularization of tourism potential, implementation of marketing activities, development of tourism products, improvements of service quality, the organization of trainings. Interesting Multilanguage tourist catalogs have been published, Georgia actively participates in international tourism exhibitions, tourism media forums held for foreign journalists, the new longterm strategy and action program have been developed for tourism development, tourist advertising display internet sites set up, the world's leading TV channels (CNN, Euro news) housed the tourist clips about Georgia, business ties with world famous tourism companies were established, the world's geographical society (National Geographic) inserted Georgia into 50 tourist country list. Georgia's achievements in tourism, including wine and cuisine articles were published in the New York Times, the Guardian, and American edition of Bloomberg, Georgia takes part in many international tourism exhibitions.

The socio-economic problems existing in $21^{\text {st }}$ century have made education development challenge a priority, since it is the education quality that grows human capital (knowledge, professionalism, high culture, skills) and represents state intellectual and spiritual resource. The state success in socioeconomic development is directly linked to the ensured education system, to the education quality of population. It is evident that traditional production factors (land, raw materials, industrial capital), have important role in state development, but they have frameworks, the development margin. Only human capital, its skills and spirituality are unlimited.

For development of human capital at the national level (macro level), it is necessary to solve the problem of the two groups: on the one hand, to find additional financial resources for the employees, belonging to the population groups and corresponding sectors of economy; on the other hand - the reforms should be carried out in these sectors. Here is the actual problem that we face to be solved in two parallel manners. At the same time we believe that they should be addressed separately. In addition, it should be noted as we consider that the solution of only one of them is the inefficient spending of time resource and waste of human and financial resources. Thus, the effective use of human capital, which in our opinion means its preparation and further improvement, may give Georgian economy the chance to increase economic growth race in coming years. According to education costs dynamics invested in human capital, the world practice shows that the education system has opportunity for normal operation, development and providing secondary education for all citizens in the case if about 5-7\% of GDP is spent in this direction.

Today, in the background of rapid development of tourism business, in hotel business is increasingly being revealed by the fact that without special educationit is impossible to provide socio-cultural services at a professional level. And the customer service area, it is simply impossible. Companies, hotels and hotel chains, which have no qualified manager staff with special skills in financial management, service equipment and technology, hotel management, tour operator activity, international service standards, etc. are doomed to failure in the competitive battle.

Georgia's tourism industry growth is original catalyst in the country's socio-economic development. This sector development contributes to the satisfaction of citizens demands, strengthening regional and international relations, stimulates the transport, communications, construction, hotel industry, trade and the development of consumer goods.

Domestic tourism has noticeably been increased in recent years in Georgia. Inside housing became more and more popular which indicates Georgian tourist infra- 
structure development, population prosperity growth and economic stabilization. But today's indices do not fully reflect the problems that have accumulated in tourism sector of economy: changed internal and external conditions, significantly worsened the region's socio-economic and political situation, adaptation to external conditions is more difficult and therefore, successful managerial policy output greatly depends on employed personnel.

The educational activity has been started and is progressing in the tourist zones in the villages in Georgia. Here enhancing their knowledge, raising qualification skill, new specialty mastering can be done by any individual. In tourist villages inhabitants are studying knowledge basics in service, tourist route planning, ecology, agriculture, technique and technology. Special attention is paid to the youth tourism development, young people visiting historical and cultural sites, organized tourist excursions with thematic training seminars on tourism development issues.

\section{Conclusion}

Thus, in our view, the most important tasks that need to be solved in hospitality industry and socio-cultural development are the following:

- To change service and private hospitality industry existing facilities in Georgia (hotels and tourist bases) in students hands-on learning centers behavior facilities. At this time the main attention should be focused on the qualification skills formation;

- Further improvement of hospitality industry regulatory legal framework and development of tourism and hotel business management system at the regional level;

- Diversified educational products to be introduced by specialized training pro- grams, professional seminars, internship programs and in the form of socio-cultural workers training courses;

- New and effective educational system formation in hospitality and services industries, which will be within the framework determined by the entire Georgian education system, modernized according the Bologna Convention. Meanwhile, the new education model of service sector must harmonically fit new technological approaches with Georgian hospitality and traditions and common principles of middle and high schools;

- To strengthen scientific - methodological base, curriculum and training programs for all learning forms, including additional, post-graduate and distance learning, besides composition of modern textbooks and methodical complexes, electronic libraries and drafting of hospitality industry new sites;

- Through creative education systems the formation of partnership interaction system with educational institutions and hotel enterprises;

- Elaboration of new conceptual approaches in educational institutions for students' practical training with sector, tourism administrations, and regional and state management agencies required representatives' complicity in the background.

Timely solution of sector problems, education system reform of hotel industry specialists, human capital management and improvement of service quality will contribute to the further development and perfection of socio-cultural sphere. Only such approach will be possible to satisfy people demand on active and full relaxation, improve their wellbeing and their communion with Georgian hospitality cultural treasure. 


\section{References}

A. Raj, (2008), Human Capital Needs and Challenges for the Tourism Sector, South Asian Journal of Tourism and Heritage, Vol. 1, No. 1

Georgian National Tourism Administration, http://gnta.ge/wp-content/uploads/2014/ 08/eng- 4print10.pdf)

Kutanis, R. and etc. (2012), 'Investigating hotelemployee involvement in strategic human resourcesmanagement , Tourismos: An Internationalmultidisciplinary journal of tourism Volume 7, Number 1, SpringSummer 2012, pp. 117-134.

Meskhia I., Asatiani R. (2012) The resort-recreational resources and tourism, "Georgian Economy", Tbilisi, p. 235.

Meskhia I. (2010). Tourism Business Environment in Georgia: Analysis and Predictions, Journal "Business and Management", p. 215.

Matis L. R et al (2012), "Management of humanResources".Maquieira, R. J, et al, 'Implications of human capitalanalysis in tourism' International handbook on theeconomics of tourism, pp. 379- 398.

Nickson, D. (2007), Human Resource management for the hospitality and tourism industries', Elsevier Ltd.

Tiwari, P. (2012) 'Human resource management practices: a comprehensive review',
Pakistan business review, pp. 669-705, January 2012

NationalStatisticsOfficeofGeorgia,http://www. geostat.ge/index.php?action $=$ page $\&$ p id=137\&lang=eng

PATAcademy-HCD: Human Capital Development - This Decade's Tourism Challenge, https://www.pata.org/human-capital-development-this-decades-tourism-challenge/

Stewart, T.A. (2004). Intellectual Capital: The New Wealth of Organization. - N.Y.2L.. -p 275.

Travel and Tourism Competitiveness Report, http://reports.weforum.org/travel-andtourism-competitiveness-report-2015

Tiwari, P. (2012) 'Human resource management practices: a comprehensive review', Pakistan business review, pp. 669-705, January 2012

World Travel and Torusim Council, (2015) https://www.wttc.org/-/media/files/reports/ economic\%20impact\%20research/countries\%202015/georgia2015.pdf

World Travel and Torusim Council, (2015)http://www.wttc.org/research/policy-research/human-capital/

Blanchard, O. (1997). The Economics of PostCommunist Transition". Oxford University Press. http://www-sre.wu-wien.ac.at/ersa/ ersaconfs/ersa04/PDF/468.pdf

C.M. Guisan,E. Aguayo, D. Carballas (2004), Human Capital, Industry, Tourism and Economic Development of EU25 Regions. 